\title{
Android-Based Information System Of Online Teaching Services With Geo-Location Determination
}

\author{
Bambang Riono ${ }^{1)^{*}}$,Widia Rifkianti ${ }^{2)}$ \\ 1)2) Pancasila University, Faculty of Engineering, Information Technology, Jakarta - Indonesia \\ $J l$, Srengseng Sawah, Jagakarsa - Jakarta \\ 1)bambang.riono@univpancasila.ac.id \\ 3) widiarifki@gmail.com
}

Article history:

Received 10 August 2018; Revised 16 August 2018; Accepted 25 August 2018; Available online 19 September 2018

Keywords:

Information System Android

Teaching Services

Geo-Location

\section{Abstract}

The information system of online teaching services with geo-location determination is a system that brings together and arranging meetings between private tutors and people looking for private tutors through Android application supported with geo-location. People can go looking for tutors of related subject for specific time of meeting and location, and then the system will search tutors with matched time of availability within nearest location radius. In addition, students can organize or plan a learning meeting session with the teacher through the application. This information system is a client-server based where the built application consists of Android applications running on the client environment and web applications running on the server environment. Mobile/client applications are used by end-users to search and organize learning session. Web applications serves as web services and interfaces for administrator to manage master data, view user and transaction data, print reports, and respond to complaints from end-users. The programming language used in building this information system is the Java programming language for mobile applications and PHP for web applications and web services. And using MySQL as the database.

\section{PREFACE}

Quality of an individual's education is influenced by many things, one of which is the learning process in the implementation of education attended. Implementation of education or teachings which generally followed by most people is the classical teaching (school).

However, when following classical teaching method, there is always a unique difference between one student and another. Therefore, the classic teaching method that is considered efficient is not necessarily able to achieve mastery target for all students due to the level of course material mastery between one student and another are varies greatly. For this reason, some people carry out private teaching methods to provide additional learning supplements or extra guidance to participants or students from external sources unobtained in the classical teaching environment (school or campus) in order to improve students' understanding and mastery of the material.

Common things done by most people, especially parents or school students when needing private tutoring services are to find out through friends, neighbors, people from around, tutoring institutions that are available or search from search engines on the internet. Sometimes they will find instructors according to the desired qualifications, sometimes they won't. Or sometimes they find a teacher but unfortunately obstructed with location problems. On the other hand, it does not rule out the possibility that there are actually people around their neighborhood or not too far from their location who actually have the teaching qualifications sought or needed. However, their whereabouts are unknown and they do not expose or open information about themselves who have qualifications as teachers. One example is college students. Probably they have the ability to teach as private tutors but not known to many in the environment they live in.

Author pays attention to this as one of the problems that can actually be overcome given the existence and

* Corresponding author

ISSN 2622-2728 (online) 2622-271X (print) @ 2018 The Authors. Published by Komunitas Dosen Indonesia.

This is an open access article under the CC BY license (http://creativecommons.org/licenses/by/4.0/) 
popularity of the use of smartphone technology today which is very unfortunate if the technological progress is not used for important needs such as learning activities. Meanwhile, the use of technology for entertainment and consumptive activities such as online shops is increasingly crowded

Looking closely at this issue, author developed an application to search for private teaching services online by determining geolocation or utilizing Location Based Service (LBS) built on the Android platform. The reason for choosing Android as the target platform for development is because its usage percentage in Indonesia reaches 74.28\%, outperforming the percentage of other mobile platforms such as iOS, Blackberry or Symbian OS (StatCounter, 2015)

\section{GEOLOCATION}

Geolocation refers to the geographic location identification from user or computational device through data collection mechanism. Usually, geolocation uses internal routing network address or GPS device to determine location (Popescu, 2012).

\section{Location Concept in Location-Based-Services}

Basically, the term location is attributed to certain place in real world. When a group of people makes an appointment, they usually will met in a certain place such as airport, café or the office. In other case, when someone wants to send a letter or package, they must know the destination address. Both examples are implying location as a place for an object in real world. Location in these terms is classified as physical location (Kupper, 2005). Physical locations are divided into 3 subcategories in relevance of location-based-services (Kupper, 2005):

a. Descriptive Location

b. Spatial Location

c. Network Location

\section{Location Based Service (LBS)}

According to (Virrantaus, et al, 2001) location based service is "information services that can be accessed with mobile devices through cellular networks and utilize the ability to use locations from mobile devices ". Similar definition stated by (Open Geospatial Consortium, 2005) that defines LBS services as" wireless-IP services that use geographic information to serve mobile users or application services that utilize mobile terminals ". LBS can be used in a variety of contexts, such as health, work, lifestyle, etc. LBS also includes services to identify the location of a person or object, such as find the nearest ATM machine or finding friend's or relative's position, and a package delivery tracking service and vehicle tracker (Kushwaha, 2011).

\section{Global Positioning System (GPS)}

GPS is a satellite infrastructure that serves positioning from many objects (Spiekermann, 2004). According to (Roth, 2004) GPS system consists of 3 segments:
a. User segment
b. Space segment
c. Control segment

\section{Sistem Global Koordinat}

To determine the position of an object on earth's surface, global coordinates are needed. Global coordinates consists of 2 components, latitude and longitude. The measurement is done relatively based on two prime meridian, equator and Greenwhich. With latitude coordinates measured based on equator (00) which stretches 00-900 to north and 00-(-900) to south. Longitude coordinates measured based on Greenwhich meridian (00) and stretches from 001800 to east and 00-(-1800) to west (Chang, 2012).

\section{Geocoding and Reverse Geocoding}

Geocoding is a address conversion (ex: "1600 Amphitheatre Parkway, Mountain View, CA") into geographic coordinates (ex: latitude 37.423021, longitude -122.083739), so then it can be used to position the marker accurately in maps (Android Developers, 2017). Reverse Geocoding is a conversion of geographic coordinates into location human-readable address. 


\section{Haversine Formula}

Haversine Formula is a method to determine the distance between two points by taking into accounts that earth is not a flat plane but it's a field that has a degree of curvature. Haversine Formula calculates the distance between 2 points based on the length of a straight line between 2 points on latitude and longitude (Chris Vennes, 2009). Form of Haversine Formula:

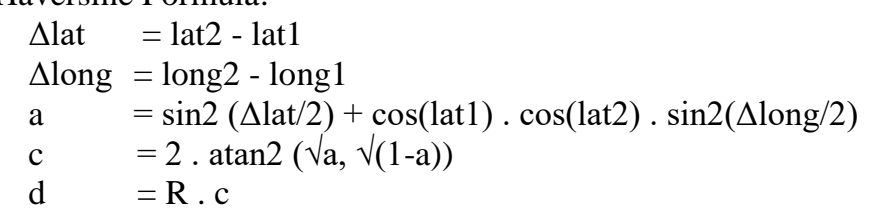

Description:

$\Delta$ lat $=$ amount of latitude change

$\Delta$ long $=$ amount of longitude change

$\mathrm{c}=$ calculation of axis intersection

$\mathrm{R} \quad=$ radius of earth $(6371 \mathrm{~km})$

$\mathrm{d}=$ distance $(\mathrm{km})$

In this research, Haversine Formula is used as a distance calculation between meet up location and tutor's location.

\section{RESTful Web Services}

RESTful Web Services is a communication method using HTTP protocol for data exchange and a common method applied to application development (Munawar Hafiz, 2011). The purpose of using RESTful as a method of data exchange between applications and databases is to make the system that has good performance, fast and easy to develop (scalable), especially in data exchange and communication.

\section{RESULTS AND DISCUSSION}

Results and discussion of the system by determining system architecture, system planning and implementation. System architecture of the information system of online teaching services with geo-location determination is a clientserver based. Which means, there are two applications built on two different environments, the web based application on server environment and Android-based on client environment with both of it utilizes same database system.

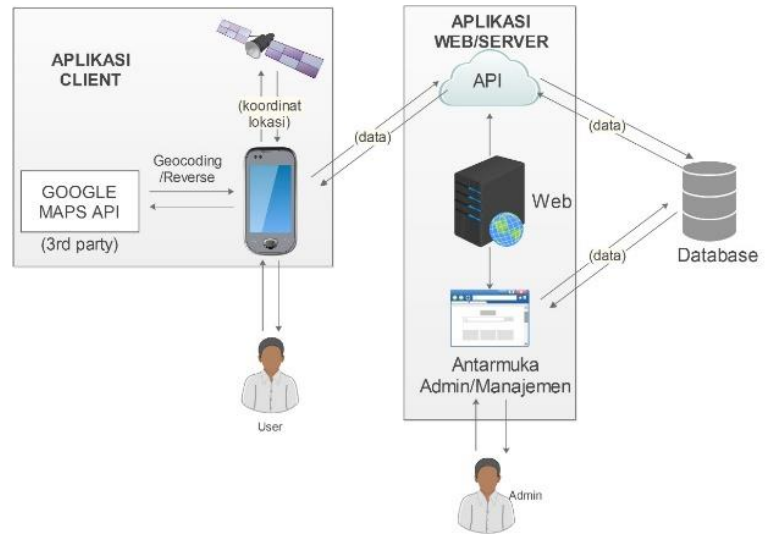

Figure 1. System Architecture

Web application serve as web services and interface for administrator to manage master data, view user data and transaction, printing reports and responding end-user complaints. The Android-based application serve as the main application for end-user to do private tutor searching and reservation, utilizing Location-based-services.

\section{System Modeling}

System modeling is done to form the results of understanding the client's needs into software requirements analysis tools that will later be used as the basis for software design. Designing a Use Case Diagram is done to determine what users can do about the software being developed (Lethbridge \& Laganiere, 2005). The Use Case Diagram is described in the figure 2 below: 


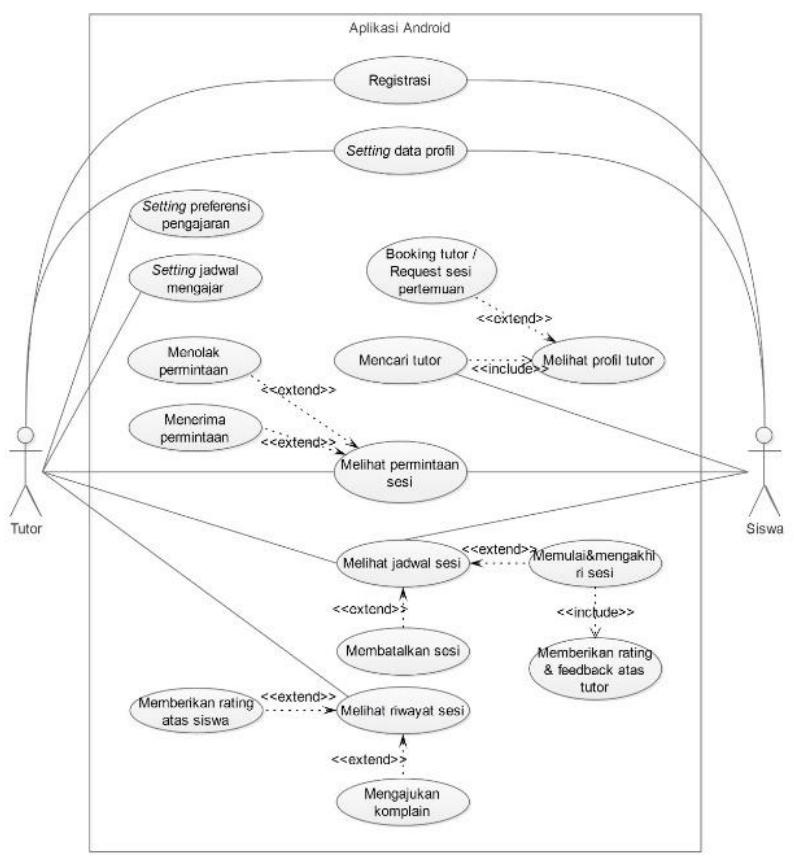

Figure 2. Use Case Diagram (Android)

The Use Case Diagram for web application/server environment is described in figure 3 below:

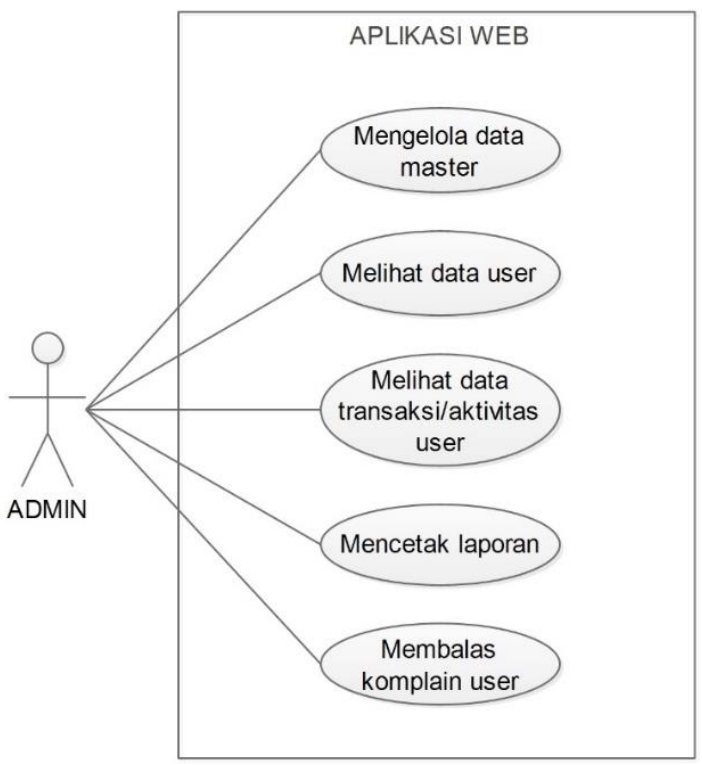

Figure 3. Use Case Diagram (Web)

Class Diagram is a UML system modeling diagram which indicates classes and association with each other (Lethbridge \& Laganiere, 2005). 


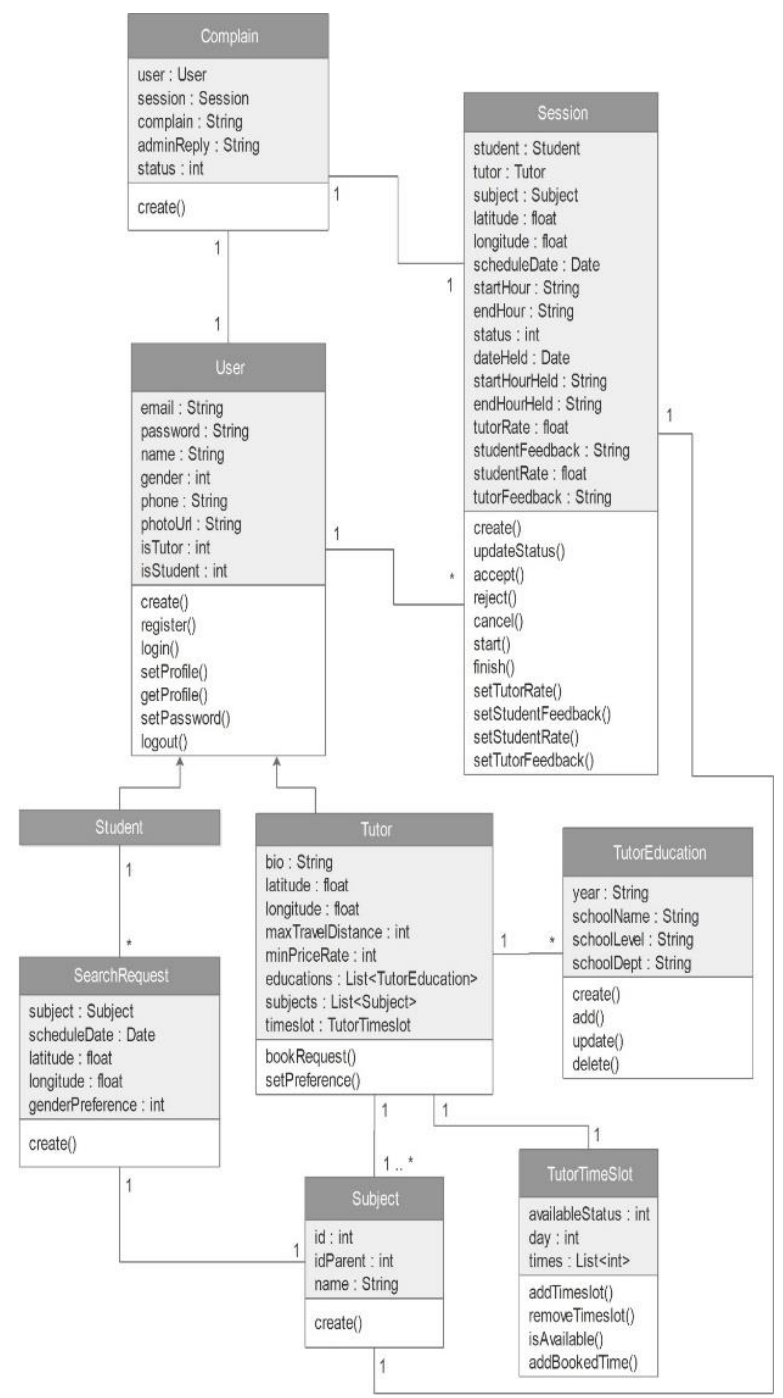

Figure 4. Class Diagram

\section{Implementation - Profile Info}

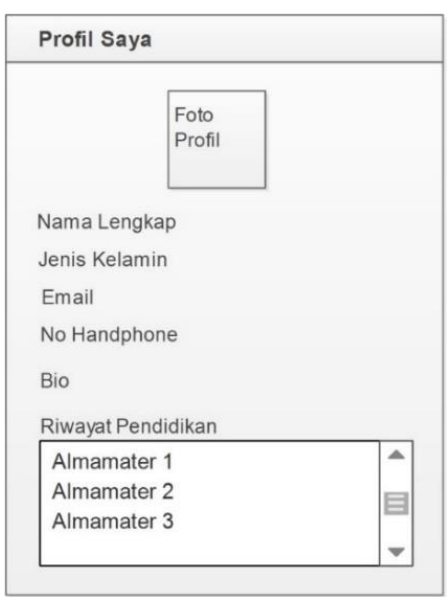

Figure 5. User Profile Info 
Output design in "My Profile" page consists of profile picture, full name, gender, e-mail address, cellphone number, bio and education history (for tutors). These information comes from data entered by user on registration process or in profile update page.

\section{Tutor Preferences Info}

\begin{tabular}{|l|l|}
\hline \multicolumn{2}{|l|}{ Preferensi Pengajar } \\
\hline Lokasi \\
Universitas Pancasila, Srengseng \\
Sawah, Lenteng Agung, Jakarta \\
Selatan \\
Maksimum Jarak Mengajar \\
5 Km \\
Tarif Minimum Mengajar (per jam) \\
Rp 50000/Jam \\
Subjek Pengajaran \\
\begin{tabular}{|l|}
\hline Subjek 1 \\
Subjek 2
\end{tabular} \\
Subjek 3 & \\
\hline
\end{tabular}

Figure 6.1 Tutor's Preferences Info

Output design in Tutor's Preferences page consists of tutor's location, preferred (maximum) distance, minimum tariff and teaching subjects. These information comes from data entered by tutor in "Tutor Preferences Settings" page.

\section{Teaching Schedule Info}

\begin{tabular}{|c|}
\hline Jadwal Tersedia \\
\hline $\begin{array}{l}\text { Senin } \\
\text { 07:00 - 12:00, 14:00 - 17:00 }\end{array}$ \\
\hline $\begin{array}{l}\text { Selasa } \\
\text { 07:00 - 12:00, 14:00 - 17:00 }\end{array}$ \\
\hline $\begin{array}{l}\text { Rabu } \\
07: 00-12: 00,14: 00-17: 00\end{array}$ \\
\hline $\begin{array}{l}\text { Kamis } \\
07: 00-12: 00,14: 00-17: 00\end{array}$ \\
\hline $\begin{array}{l}\text { Jumat } \\
07: 00-12: 00,14: 00-17: 00\end{array}$ \\
\hline $\begin{array}{l}\text { Sabtu } \\
\text { Tidak ada jadwal }\end{array}$ \\
\hline $\begin{array}{l}\text { Minggu } \\
\text { Tidak ada jadwal }\end{array}$ \\
\hline
\end{tabular}

Figure 7. Teaching Schedule Info 
Output design of "Tutor's Availability Schedule" consists of the tutor's availability for each day. These information comes from data entered by tutor in "Teaching Schedule Settings" page.

\section{Tutor Search Results}

\begin{tabular}{|c|c|}
\hline \multicolumn{2}{|c|}{ Hasil Pencarian } \\
\hline \begin{tabular}{|l} 
Foto \\
Profil \\
Tutor
\end{tabular} & $\begin{array}{l}\text { Nama Tutor } \\
\text { Institusi Pendidikan/Almamater } \\
\text { Subjek Pelajaran/Bidang }\end{array}$ \\
\hline \multicolumn{2}{|c|}{$\begin{array}{l}\text { Rate Harga Pengajar - Jarak lokasi } \\
\text { Rating Total }\end{array}$} \\
\hline \begin{tabular}{|l} 
Foto \\
Profil \\
Tutor \\
\end{tabular} & $\begin{array}{l}\text { Nama Tutor } \\
\text { Institusi Pendidikan/Almamater } \\
\text { Subjek Pelajaran/Bidang }\end{array}$ \\
\hline \multicolumn{2}{|c|}{$\begin{array}{l}\text { Rate Harga Pengajar - Jarak lokasi } \\
\text { Rating Total }\end{array}$} \\
\hline $\begin{array}{l}\text { Foto } \\
\text { Profil } \\
\text { Tutor }\end{array}$ & $\begin{array}{l}\text { Nama Tutor } \\
\text { Institusi Pendidikan/Almamate } \\
\text { Subjek Pelajaran/Bidang }\end{array}$ \\
\hline $\begin{array}{l}\text { Rate } 1 \\
\text { Rating }\end{array}$ & Pengajar - Jarak lokasi \\
\hline
\end{tabular}

Figure 7. Tutor Search Results

Output design of "Tutor Search Results" page consists of available tutors to be booked. The results are filtered based on parameters entered by students in "Tutor Search" page, with the parameters are teaching subject, preferred location (with certain coordinates), preferred schedule and preferred gender.

\section{Tutor Profile}

\begin{tabular}{|c|c|}
\hline \multicolumn{2}{|c|}{ Profil Lengkap Tutor } \\
\hline $\begin{array}{l}\text { Foto } \\
\text { Profil } \\
\text { Tutor }\end{array}$ & $\begin{array}{l}\text { Nama Tutor } \\
\text { Jml siswa yg memfavoritkan } \\
\text { Sesi yg telah diselesaikan }\end{array}$ \\
\hline \multicolumn{2}{|c|}{$\begin{array}{l}\text { Rate harga pengajar } \\
\text { Lokasi/Area mengajar tutor }\end{array}$} \\
\hline $\begin{array}{l}\text { Profil D } \\
\text { Bio / T } \\
\text { Email } \\
\text { No Tele } \\
\text { Riwaya }\end{array}$ & r \\
\hline $\begin{array}{l}\text { Subjek } \\
\text { Subjek } \\
\text { Subjek } \\
\text { Subjek }\end{array}$ & ajaran \\
\hline \multicolumn{2}{|c|}{$\begin{array}{l}\text { Komentar \& Rating Siswa } 1 \\
\text { Komentar \& Rating Siswa } 2 \\
\text { Komentar \& Rating Siswa } 3\end{array}$} \\
\hline
\end{tabular}

Figure 8. Tutor Profile Info

Output design of "Tutor Profile" page consists of complete information of tutors including profile picture, tariff, location, bio, e-mail address, education history, teaching subjects and other information such as student reviews, 
number of users/students who favors and number of completed sessions. These information comes from user data and transaction/completed session.

\section{Session Requests List}

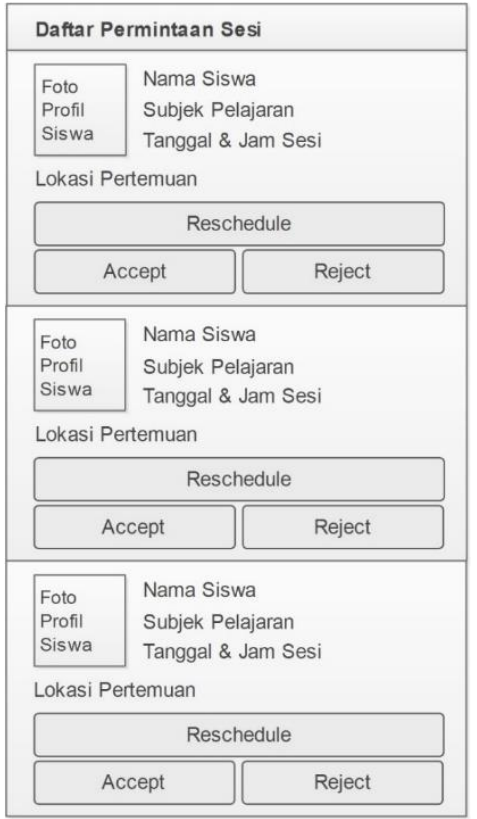

Figure 9. Session Requests List

Output design of "Session Requests List" page consists of sessions requested by students towards the tutor. The detailed information consists of student's profile picture, name, teaching subject, requested time and meet up location, along with buttons to accept or reject the request. These information comes from session request entered by users (students).

\section{Current and Upcoming Sessions List}

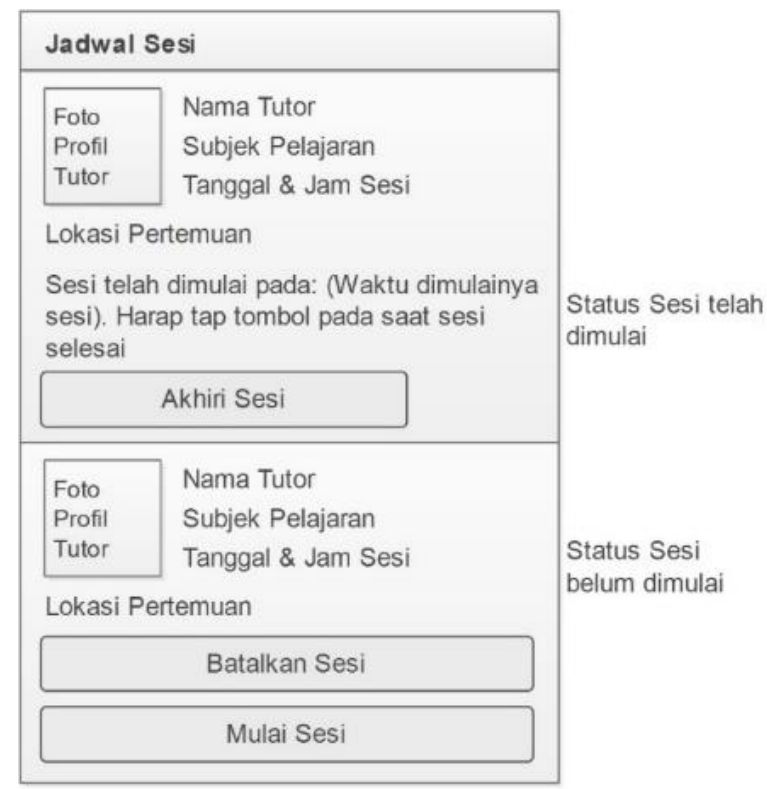

Figure 10. Current and Upcoming Sessions List (Logged in as student). 


\section{CONCLUSION}

Information system of online teaching services with geo-location determination is an online application runs on Android platform to bring together private tutors and students looking for private tutors through Android-based application with geo-location based searching and manage bookings scheduled meetings. The targeted users from this application are general public.

\section{REFERENCES}

[1] Axel Kupper. 2005. Location-Based Services, Fundamentals and Operation. Wiley

[2] Axel Kupper. 2005. Developing GIS-Supported Location-Based Services. Wiley.

[3] Hassan Gomaa. 2011. Software Modelling \& Design. Cambridge: Cambridge University Press. http://developer.android.com.

[4] Popescu. 2012. Geolocation API Spesification. https://dev.w3.org/geo/api/spec-source.html. W3C. Diakses tanggal 1 Juli 2017.

[5] Roth J. 2004. Aspects of communication in LBS. Di dalam: Schiller J, Voisard A, editor. Location-Based Services. San Francisco (US): Morgan Kauffman.

[6] Ryan Herwan, Herry Sujiani, Novi Safriadi. 2015. Penerapan Metode Haversine Formula Pada Sistem Informasi Geografis Pengukuran Luas Tanah. Jurnal Sistem dan Teknologi Informasi (JUSTIN) Vol. 1, No. 1.

[7] Sheran A. Gunasekera. 2012. Android Apps Security. Apress

[8] Schiller J, Voisard A, editor. Location-Based Services. San Francisco (US): Morgan Kaufmann

[9] Spiekermann S. 2004. General aspects of location-based services. Di dalam: Schiller J, Voisard A, editor. Location-Based Services. San Francisco (US): Morgan Kaufmann

[10] Timothy C. Lethbridge. 2005. Object Oriented Softwre Engineering. Berkshire: McGraw Hill 